\title{
The Land of Saints UCH Sharif
}

\author{
Nusrat Bibi* \\ Department of Textile Design, University College of Art \& Design, Faculty of Arts, The Islamia University of Bahawalpur, Pakistan \\ DOI: 10.29322/IJSRP.11.10.2021.p11832 \\ http://dx.doi.org/10.29322/IJSRP.11.10.2021.p11832
}

\begin{abstract}
Uuch Sharīf is located near about $25 \mathrm{~km}$ from Ahmadpur Sharqia and $90 \mathrm{~km}$ from Bahawalpur City, a historic city in the southern part of Pakistan's Punjab province. Uch may additionally have been headquartered as Alexandria on the Indus, a city founded through Alexander the Great throughout his invasion of the Indus Valley. Uch Sharif was an early stronghold of the Delhi Sultanate at some point of the Muslim conquest of the subcontinent also recognized as domestic for the Bukhari's after the migration from Bukhara. Uch Sharif was once a regional metropolitan middle between

the twelfth and seventeenth centuries and became refuge for Muslim spiritual pupils fleeing persecution from different lands. Though Uch is now a distinctly small city, it is renowned for intact ancient urban fabric, and for its series of shrines committed to Muslim mystics. Uch Sharif is the land of saints. This city has its own history like cities like Multan, Baghdad and Egypt is a city of about five thousand years old. History shows that one hundred thousand saints are buried here. It was an important centre in medieval India. Uch Sharif is
\end{abstract}

considered master pieces of Islamic architecture and is on the UNESCO World Heritage Site tentative list.

Index Terms- Land, Saints, Uch, History, Religious, Saints

\section{INTRODUCTION}

$\mathrm{U}$ ch Sharif is also called the land of saints. Separately from a grave attributed to a grandson of the Arab Caliph Abu Bakar Sadeeq and a tutor to Hazrat Imam Husain," the grandson of the Holy Prophet (SAW) there are no traces of any shrines constructed during the duration that Bahawalpur was under Arab rule. The town of Holy Uch Sharif enrichment to prominence in this era though has little to show for it architecturally. However, Uch Sharif in consequence increased a worldwide status in the way of periods of Muslim rule in primitive, successful as a center of faith and studying with the entrance of mystics from locations such as Baghdad.

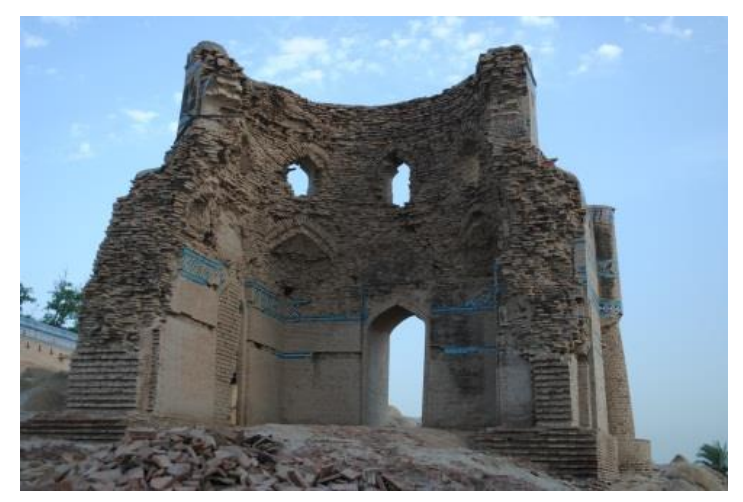

\section{BAHA'AL-HALIM TOMB MONUMENT COMPLEX}

The shrine of Baha'al-Halim viewpoints in the northwest location of Uch Sharif on the sloping facet of a hill, the location of an old fort, amongst the ruins of several different architecturally momentous graves. One of the first Muslim mystics who came to Uch Sharif in AD 981 from the Persian town, was Sayid Safi Ad-Din" AD 1007. He constructed a khangah in Uch Sharif a commodious constructing that controlled a madrassa and housing area, and could accommodate near about 500 to 600 students at a time. The second such building built in Uch Sharif was also an instructional organization, constructed in the twelfth century and named Madrassa Ferozia. It used to be even larger than Ghazrunis seminary, constructed to quarter greater than 2,500 college students at a time. The famed historian additionally taught right here for a time. 


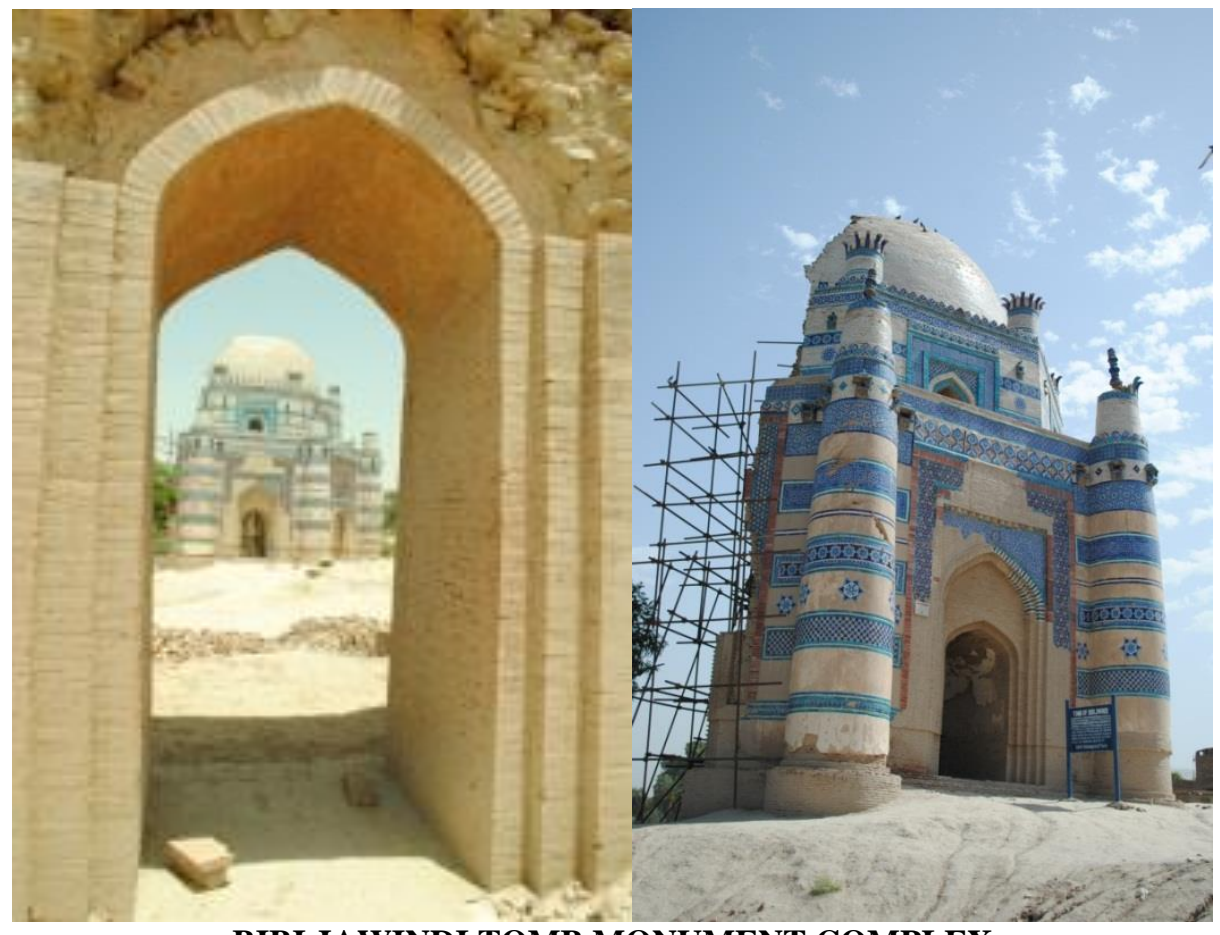

BIBI JAWINDI TOMB MONUMENT COMPLEX

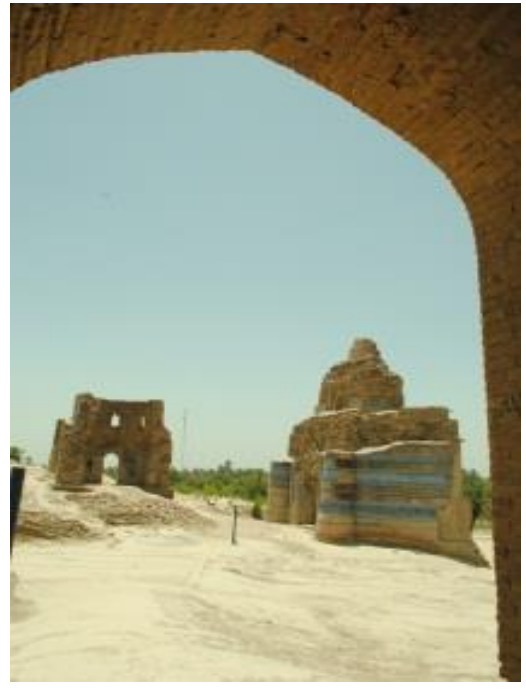

NURIA AND BAHA'AL-HALIM MONUMENT COMPLEX 

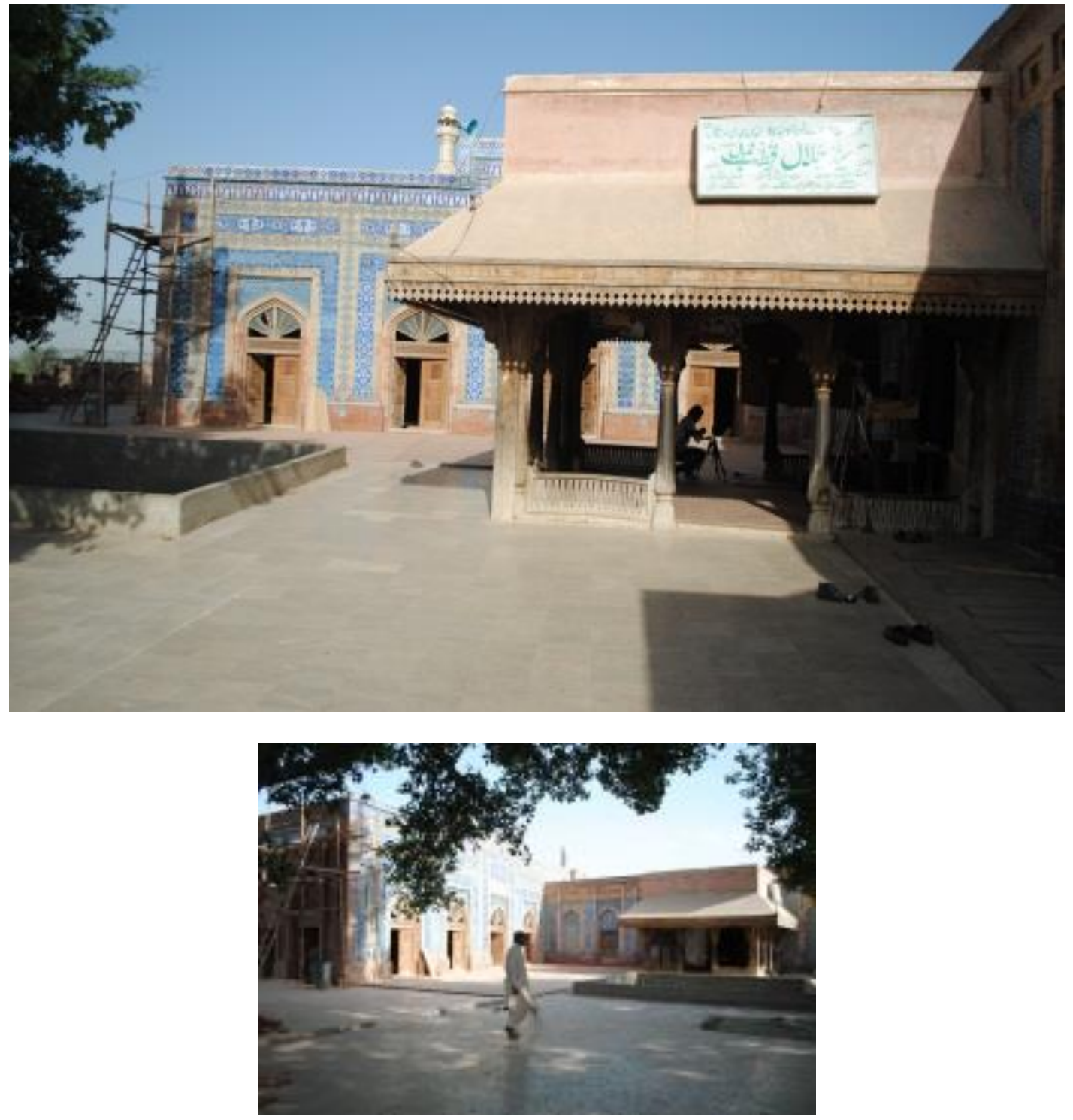

\section{JALALUDDIN BUKHARI TOMB AND MOSQUE}

Jalaluddin Surkh-Posh Bukhari used to be a Sufi virtuous and missionary who lived from 12 th to thirteenth century. He was once lively in translating nearby ethnic crew and Islam, amongst them the Chhadars, Dher and Siyal.

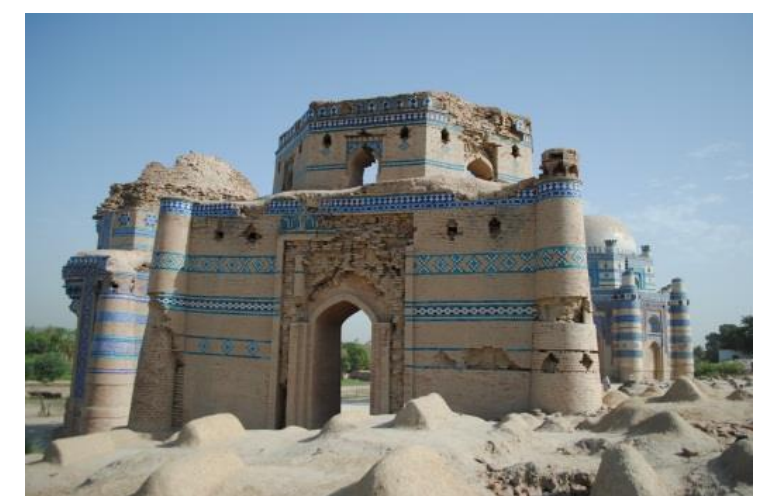


The shrine of Ustad Nuriya positions in the northwest corner of Uch Sharif on the sloping side of a hill, the spot of an historic fortress, some other architecturally essential shrine, among them shrines of BIBI JAWINDI \& BAHA'AL-HALIM.
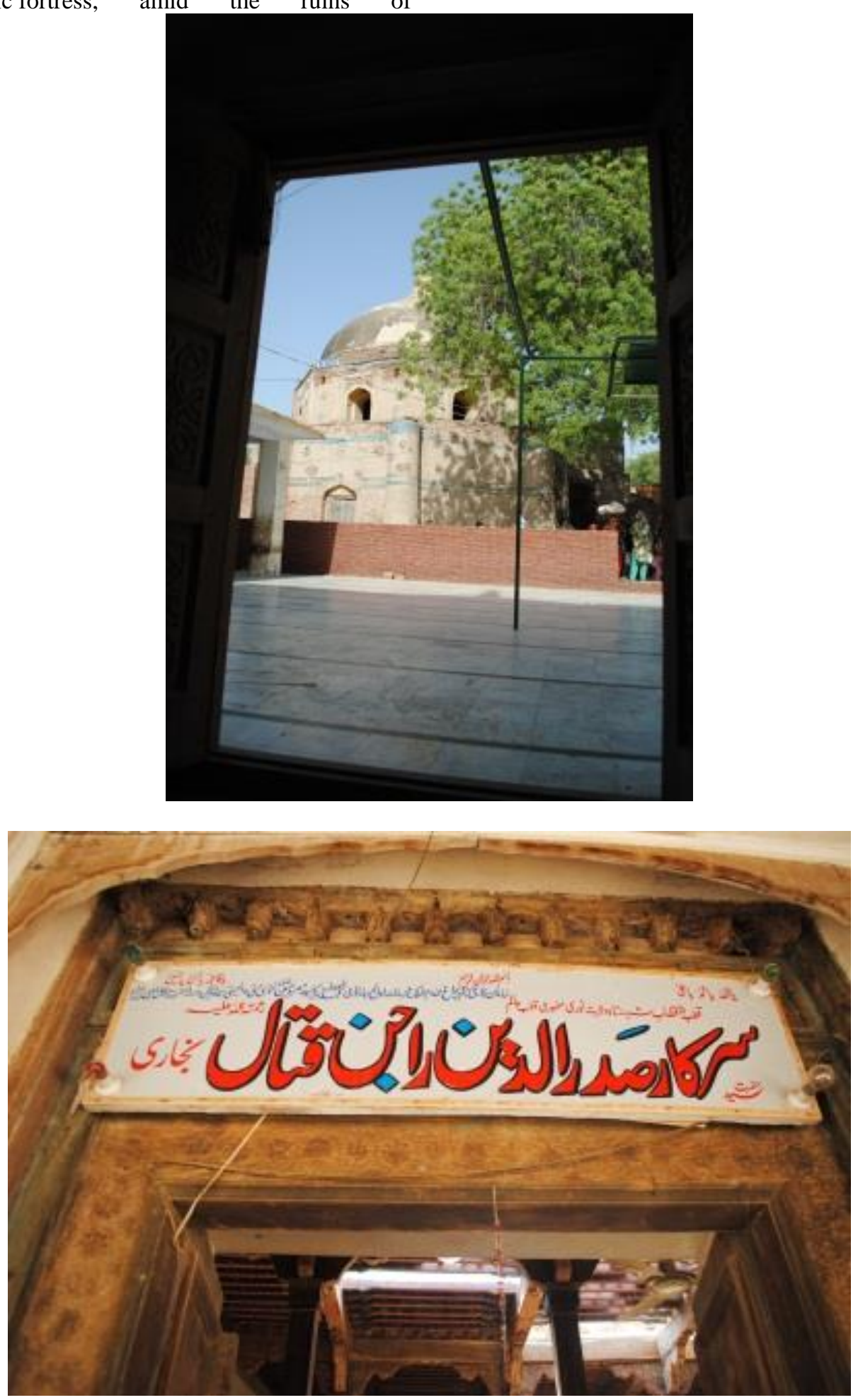

RAJAN QATTAL TOMB AND MOSQUE

The shrine of Rajan Qattal is a properly sample of the flatroofed tomb building customized at Uch Sharif. The graph generally incorporates of a large rectangular funereal chamber with the grave of a unique luminary reside in an important location. The school won global status and concerned college students from all over India as properly as from the Middle East. It succeeded especially underneath Nasir ud-Din Qabacha, one of the slaves of Sultan Qutab Ud-Din Aibak, who, after Aibak's death, set up his government in the region in AD 1210 and made Uch Sharif his capital. In the thirteenth centuries, 
Uch Sharif grew to become a leading center for spirituality in India, Spiritualists such as Shah Naseer ad-Din Chiragh-e-Dehlvi, his teacher Baba Farid Ganj Shakar," and many others got here to the khanqah at Uch Sharif for quiet and chilas. With the permanent rise of religion in India, and in Uech Sharif in particular, rankings of new structures had been in all likelihood constructed at some stage in this period-khangahs, madrassahs, mosques, shrines, tombs, wells, fortification walls, doorways, fortresses, and forts. The three main clearings in Uch Sharif at the time had been Uch Bokharı, Uch Gilani, and Uch Mughlan. In some senses, mediaeval Uch Sharif construction established from the Multan school, combination traces of Central Asian, Persian, and local inspiration. The monuments of this dated can be incompletely divided into two types, in phrases of constructing method, development and design. The main kind of building is established in a variety of Uch Sharif shrines, these have a tendency to be octagonal, threestorey constructions with area for circumambulation on the main floor and oblique walls.

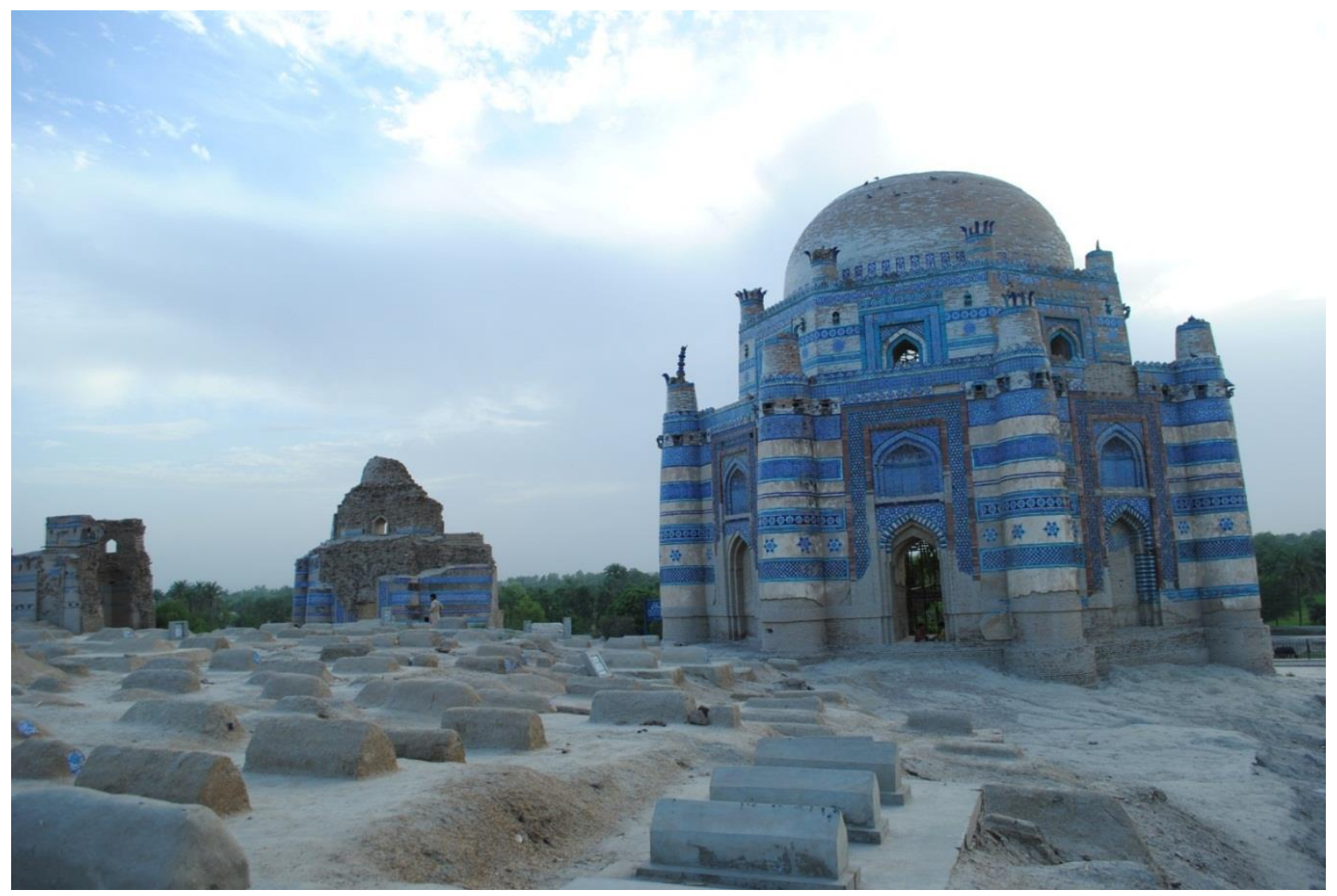

They are supported by means of octagonal buttresses and often, octagonal pepper pot-shaped turrets at the corners. The turrets are distinct, enhanced drums surmounted by huge semicircular domes by possible of zones of transition, and crowned with complex pinnacles. The indoors and exterior of these buildings have been architecturally heightened with faiencemosaic and great timber framing and squinches that are constantly used inside the brick core to permit flexibility, and as structural elements. This grace of building is categorized first-rate via the shrine of the mystic, Bibi Jawindi and the tombs of Baha Al-Halim and Musa Pak Shaheed. The first three monuments are similar in building method and architectural grace, and are properly extensions of the Multan college of architecture, specially stimulated by using the tomb of Shah Rukn-i-Alam. The tomb of Bibi Jawindi was constructed by a prince of Khurasan, Muhammad Dilshad, in $\mathrm{AD} 1493$ and is a placing example of structure comportment the traces of Central Asia. The another storey is octagonal and very low in height. The parapets of the two lower tiers are marked with false merlons of glazed tiles; that of the first bears the inscription 'Allah'. The construction's changeover region consists of a blended beam and braces and series of squinches. The $1 / 3$ storey is a hemispherical dome with a finial at the top. The tomb additionally has four arched clerestory windows. The external surface of the shrine 


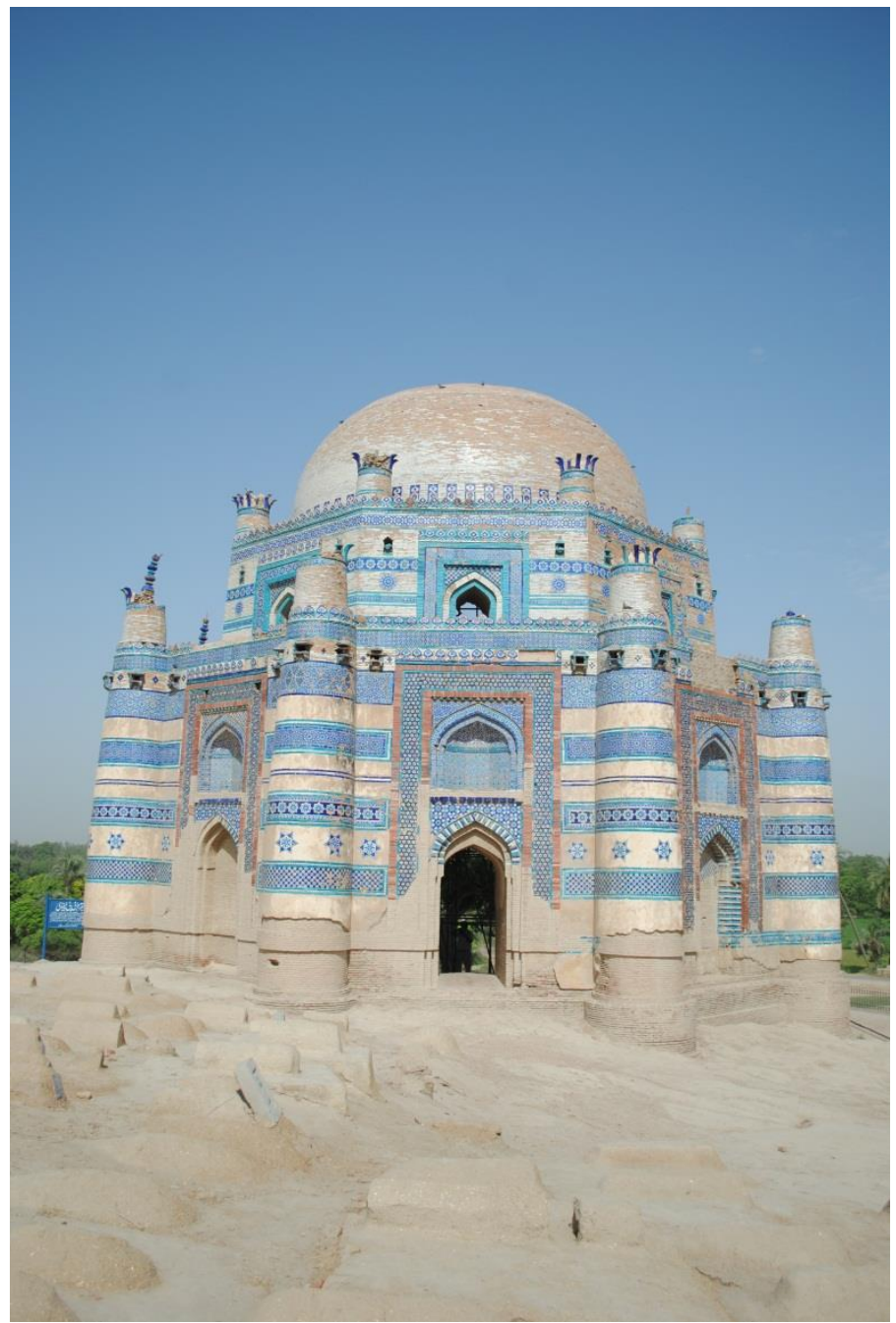

is embellished with Multani tiles that show geometrical and floral patterns. The second instance of this architectural crew is the $15^{\text {th }}$ century tomb of Baha al-Halim, a renowned student of Uch Sharif who also taught Sayyid Jalal-ad-Din Jahanian Jahangasht. The $2 \mathrm{~d}$ fashion of architecture in Uch Sharif is categorized by way of rectangular or square halls, flat, wooden roofs with problematic lacquer work of floral and geometric patterns maintained by way of wooden beams, columns, battens, and carved brackets. Wooden screens bearing common Islamic geometrical patterns are abundantly used for ventilation and daylight. 


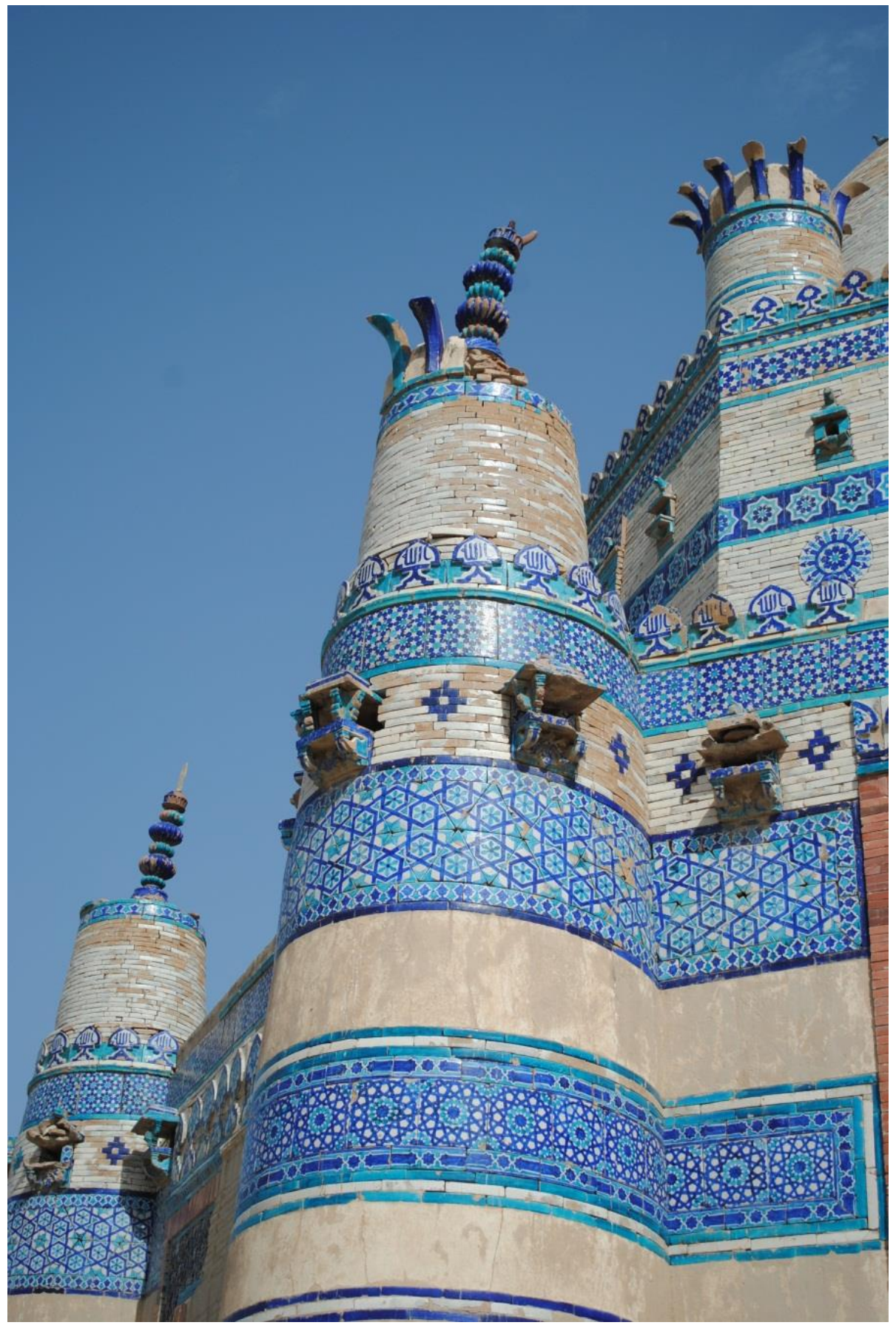

The influence of the Multan College and its architectural roots are strongly superficial here. The variations of time have wasted many of Uch Sharif most magnificent shrines. There are nonetheless traces of limited, monuments that symbolize a $1 / 3$ birthday celebration class of Uch Shari building. Some classical references indicate that this may also be the ancient fortress captured via Muhammad Bin Qasim in AD 712 , but this is hard to verify. The mediaeval structures of Uch Sharif are an important supply of statistics on the history and improvement of Sultanate period building in Pakistan, and the influence that $10^{\text {th }}$ and $11^{\text {th }}$ century Central Asia had on style, building material, and façades. 


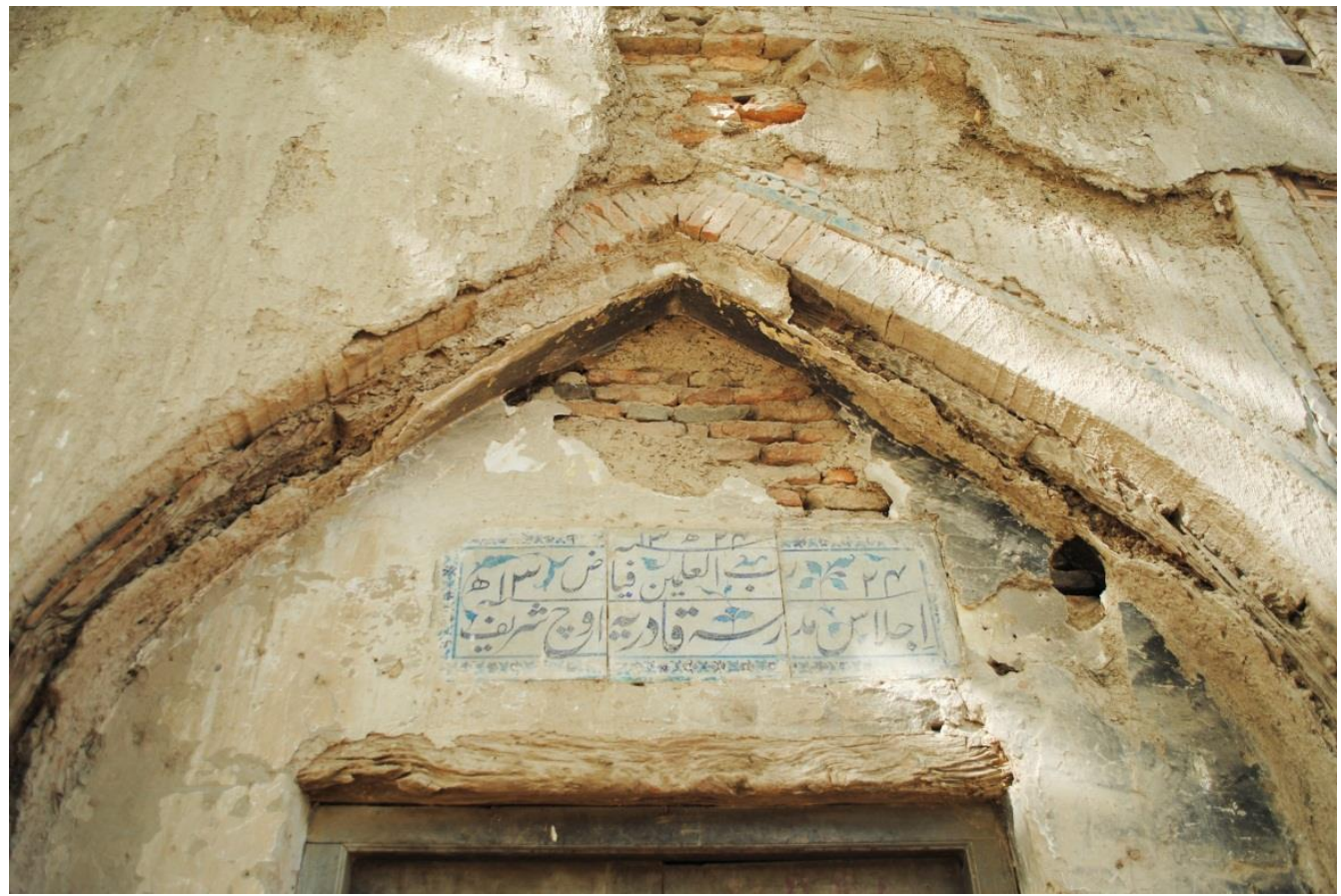

This technique emerged for the period of the

It became hugely popular and persevered till the starting of the Tughlaq duration in central Punjab, after being custom-made to the local atmosphere and civilizations.

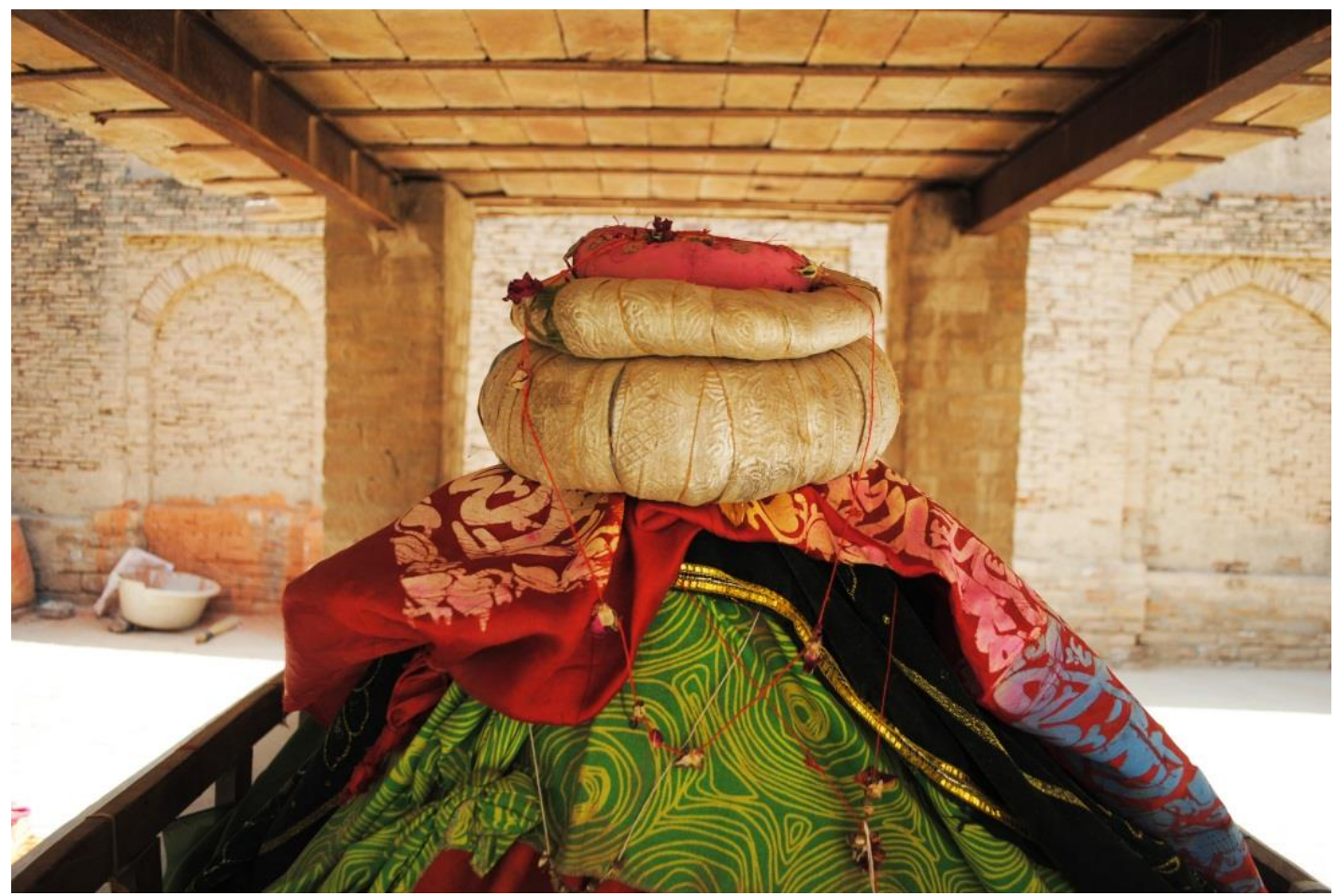




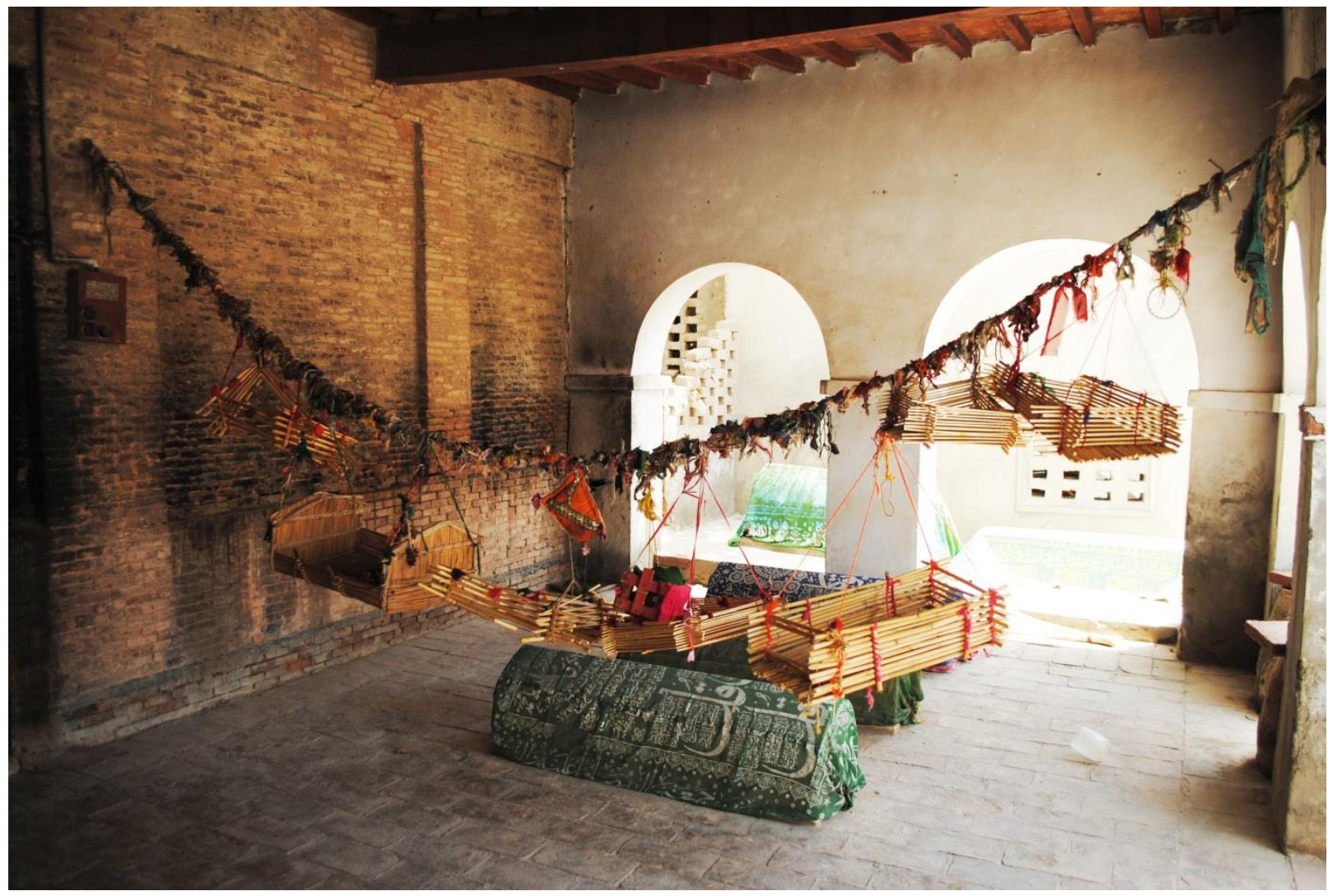

Prayers tied up in threads, Uch Sharif.

Religious and Spirituals people from all over the Pakistan often visit Uch Sharif.

\section{REFERENCES}

[1] Yasmin Cheema, Jonathan Stanhope Bell. (October, 2014). A Scientific Methodology for Conservation: Safeguarding the Bibi Jawandi Tomb Complex, Uch Sharif, Pakistan. https://www.researchgate.net/publication/297917853.

[2] Kashif Zafar (February 06, 2017). Uch Sharif: where the shrine culture began. THE EXPRESS TRIBUNE.
[3] Muhammad Hassan Miraj (June 30, 2014). UCH SHARIF 11. DAWN.

[4] Traveling Omi (Aug 24, 2020). Uch Sharif Complete History in Urdu | Asian Historical Cultural Architecture | Old Book City Visit. Available at YouTube

[5] The City of Nawabs. Uch Sharif. MyBahawalpur.com

\section{AUTHORS}

First Author - Nusrat Bibi (Assistant Professor), Department of Textile Design, University College of Art \& Design, Faculty of Arts, The Islamia University of Bahawalpur, Pakistan, Mail ID: nusratbibi1987@gmail.com, Cell\# 03008667684 